\title{
Acetogenic Bacteria Mainly Contribute to the Disposal of Hydrogen in the Colon of Healthy Japanese
}

\author{
Yuji OHashi*, Ayako Andou, Miho Kanaya, Keisuke HaRada and Tomohiko FuJISAWA \\ Laboratory of Food Hygiene, Department of Food Science and Technology, Nippon Veterinary and Life Science University, 1-7-1 \\ Kyonan-cho, Musashino, Tokyo 180-8602, Japan
}

Received September 4, 2008; Accepted November 5, 2008

Hydrogen-utilizing bacteria in the feces of Japanese individuals were analyzed with the specific polymerase chain reaction targeting the functional genes. The formyltetrahydrofolate synthetase gene derived from acetogenic bacteria was predominantly detected in all subjects. We consider that reductive acetogenesis might be an important $\mathrm{H}_{2}$ disposal pathway in healthy Japanese.

Key words: acetogenic bacteria; methanogenic archaea; sulfate-reducing bacteria; hydrogen; colonic fermentation

Intestinal bacteria ferment undigested food materials and endogenous substances, such as mucus. Short-chain fatty acids, carbon dioxide, and hydrogen are produced during this fermentation. In the process of anaerobic fermentation, hydrogen must be removed to allow the reoxidation of electron carriers that are essential to the fermentation process (24). Hydrogen-utilizing bacteria, such as sulfate-reducing bacteria, methanogenic archaea, and acetogenic bacteria, contribute to the disposal of hydrogen in the mammalian large intestine $(2,8)$. Sulfatereducing bacteria are obligatory anaerobic bacteria that utilize hydrogen and sulfate as an electron donor and an electron acceptor, respectively (7). The major end product of sulfate reduction is sulfide. Sulfide inhibits butyrate oxidation in colonic epithelial cells (17). Because butyrate plays a physiological role in colonocytes, such as the upregulation of ion transports, stimulation of mucin synthesis, increase of colonic blood flow, and stimulation of growth on colonic epithelial cells $(4,21)$, it has been suggested that sulfide produced by sulfate-reducing bacteria is involved in chronic intestinal diseases, such as ulcerative colitis (20). Sulfate-reducing bacteria found in the human colon belong to the genera Desulfovibrio, Desulfobacter, Desulfomonas, Desulfobulbs, and Desulfotomaculum (10). Methanogenic archaea utilize $\mathrm{H}_{2}$ to reduce $\mathrm{CO}_{2}$ and produce methane. The predominant methanogenic archaea in the human large intestine is Methanobrevibacter smithii (16). Acetogenic bacteria utilize $\mathrm{H}_{2}$ to reduce $\mathrm{CO}_{2}$ and form acetate (14). The predominant acetogenic bacteria in the human intestinal

*Corresponding author. Mailing address: Laboratory of Food Hygiene, Department of Food Science and Technology, Nippon Veterinary and Life Science University, 1-7-1 Kyonan-cho, Musashino, Tokyo 180-8602, Japan. Phone: +81-422-51-6121. Fax: +81-422-52-9984. E-mail: ohashi@nvlu.ac.jp tract are Ruminococcus productus (18). These hydrogenutilizing microbes compete for $\mathrm{H}_{2}$ in an anaerobic fermentation system. In about $30-50 \%$ of the people from European countries, methanogenesis has been shown to be an important $\mathrm{H}_{2}$-disposal pathway (10). In 85-90\% of the people from African countries, methane production was the main method of $\mathrm{H}_{2}$ disposal $(8,9)$. In nonmethane producers, $\mathrm{H}_{2}$ was consumed with sulfate reduction or reductive acetogenesis $(2,3,10,19)$. The predominant $\mathrm{H}_{2}$ disposal bacteria in the human colon seem to differ across ethnic groups $(9,22)$, and the hydrogen-utilizing microbes in Japanese have not yet been investigated. In this study, we analyzed sulfatereducing bacteria, methanogenic archaea, and acetogenic bacteria in the feces of Japanese individuals with the specific polymerase chain reaction (PCR) targeting the functional genes, adenosine-5'-phosphosulfate (APS) reductase (5), methyl-coenzyme $\mathrm{M}$ reductase $(\operatorname{mcr} A)$ (23), and formyltetrahydrofolate synthetase (FTHFS) (13).

A total of 27 fecal samples from healthy volunteers (22 males and 5 females) aged between 21 and 24 years old were analyzed. Bacterial DNA was extracted from $0.1 \mathrm{~g}$ of feces as described by Godon et al. (11). Partial APS reductase, $\operatorname{mcr} A$, and the FTHFS gene were amplified with PCR using specific primers (Table 1). The PCR conditions were as follows: $10 \mathrm{mmol} / 1 \mathrm{Tris}-\mathrm{HCl}(\mathrm{pH}$ 8.3), $50 \mathrm{mmol} / 1 \mathrm{KCl}, 1.5 \mathrm{mmol} / 1 \mathrm{MgCl}_{2}, 160 \mu \mathrm{mol} / 1$ of each deoxynucleoside triphosphate (dNTP), $400 \mu \mathrm{mol} / 1$ of each primer, $1 \mathrm{U}$ rTaq polymerase (TOYOBO, Tokyo, Japan), and $1 \mu$ l of extracted bacterial DNA in a total volume of $25 \mu \mathrm{l}$. The PCR for APS and $m c r A$ was performed as follows: initial denaturation at $94^{\circ} \mathrm{C}$ for 3 min, followed by 30 cycles of denaturation at $94^{\circ} \mathrm{C}$ for 30 sec, annealing for $30 \mathrm{sec}$ and elongation at $72^{\circ} \mathrm{C}$ for 30 
Table 1. Specific primers used in this study

\begin{tabular}{lllc}
\hline Target & Primer & \multicolumn{1}{c}{ Sequence $\left(5^{\prime}-3{ }^{\prime}\right)$} & Reference \\
\hline APS & APS-f & TGGCAGATMATGATYMACGGG & 5 \\
& APS-r & GGGCCGTAACCGTCCTTGAA & \\
$m c r A$ & ML-f & GGTGGTGTMGGATTCACACARTAYGCWACAGC & 23 \\
& ML-r & TTCATTGCRTAGTTWGGRTAGTT & \\
\multirow{2}{*}{ FTHFS } & FTHFS-f & TTYACWGGHGAYTTCCATGC & 13 \\
& FTHFS-r & GATTTGDGTYTTRGCCATACA & \\
\hline
\end{tabular}

$\mathrm{sec}$, and final elongation at $72^{\circ} \mathrm{C}$ for $5 \mathrm{~min}$. The annealing temperatures for APS and $m c r A$ were $60^{\circ} \mathrm{C}$ and $55^{\circ} \mathrm{C}$, respectively. For the detection of FTHFS, the touchdown thermal cycling PCR was performed according to Ohashi et al. (18). The touchdown thermal cycling protocol used initial denaturation at $94^{\circ} \mathrm{C}$ for 3 min, followed by 9 cycles of denaturation at $94^{\circ} \mathrm{C}$ for 30 sec, annealing at $63^{\circ} \mathrm{C}$ for $30 \mathrm{sec}\left(\right.$ decreased by $1^{\circ} \mathrm{C}$ per cycle to $55^{\circ} \mathrm{C}$ ), and elongation at $72^{\circ} \mathrm{C}$ for $75 \mathrm{sec}$. After the touchdown portion of the protocol was completed, 20 additional cycles under an annealing temperature of $55^{\circ} \mathrm{C}$ were performed, and this was followed by a final elongation step consisting of $72^{\circ} \mathrm{C}$ for $5 \mathrm{~min}$. Aliquots of the PCR amplicons $(10 \mu 1)$ were analyzed by electrophoresis on $1.5 \%(\mathrm{w} / \mathrm{v})$ agarose gels and visualized after staining with ethidium bromide.

The results of detection by specific PCR are shown in Table 2. In the PCR-based analysis of fecal samples, the sensitivity of PCR is around $10^{5}$ to $10^{6}$ cells/g of feces (15). Therefore, the number of hydrogen disposable bacteria for which the target gene was not detected by specific-PCR in this study might be lower than $10^{6}$ cells/ $\mathrm{g}$ feces. $m c r A$ was detected from only one female subject. The other 11 subjects might be non-methane producers because the numbers of methanogens in methane producers are over $10^{7}$ to $10^{10} / \mathrm{g}$ feces $(1,6)$. The ratio (4\%) of healthy Japanese individuals who had large populations of methanogenic archaea in their intestines was much lower than that of people from both European $(30-50 \%)(10)$ and African $(85-90 \%)(9,10)$ countries. Methanogenesis does not appear to be the major $\mathrm{H}_{2}$ disposal pathway in the healthy Japanese. It has been suggested that a genetic factor in the host could have an effect on the colonization of methanogenic archaea (12). The possibility of the presence of a receptor for methanogenic archaea has also been suggested (12). Most Japanese might not have the receptor for methanogenic archaea in their gastrointestinal tract.

In non-methane producers, sulfate-reducing bacteria or homo-acetogenic bacteria contribute to $\mathrm{H}_{2}$ disposal ( 1 ,
Table 2. Detection of hydrogen-utilizing microbes with specific PCR targeting the functional genes in the feces of Japanese individuals

\begin{tabular}{lcc}
\hline \multirow{2}{*}{ Target } & \multicolumn{2}{c}{ Numbers of positive subjects } \\
\cline { 2 - 3 } & Male & Female \\
\hline APS & $0 / 22$ & $0 / 5$ \\
$m c r A$ & $0 / 22$ & $1 / 5$ \\
FTHFS & $22 / 22$ & $5 / 5$ \\
\hline
\end{tabular}

$6,10)$. However, the APS gene was not detected in any subject. This suggests that sulfate-reducing bacteria might not be significant $\mathrm{H}_{2}$-consuming bacteria among healthy Japanese. On the other hand, the FTHFS gene was detected in all subjects in this study. Therefore, reductive acetogenesis was considered to be an important $\mathrm{H}_{2}$ disposal pathway in healthy Japanese. For sulfatereducing bacteria, sufficient sulfate is required for the predominant utilization of $\mathrm{H}_{2}$ (10). The amount of mucins secreted by the host and their degree of sulfation affect the growth of sulfate-reducing bacteria because sulfate is released by the degradation of colonic mucins by clostridia and the bacteria of the Bacteroides fragilis group (10). The dietary sulfate level is also likely to affect sulfate-reducing activity, and dietary components are likely to play an important role in the colonization and activity of sulfate-reducing bacteria. The luminal $\mathrm{pH}$ may also be an important factor for the $\mathrm{H}_{2}$ disposal pathway in the large intestine (8). An alkaline $\mathrm{pH}$ is optimal for sulfate-reducing bacteria, whereas a neutral $\mathrm{pH}$ is optimal for methanogenic archaea. Acetogenesis is promoted by acidic conditions. Although the factors controlling $\mathrm{H}_{2}$-consuming bacteria in the large intestine of Japanese are poorly understood, the luminal conditions in the large intestine of healthy Japanese might not suit the growth of sulfate-reducing bacteria. Consequently, reductive acetogenic bacteria may predominantly consume $\mathrm{H}_{2}$ in the large intestine of healthy Japanese. This might be preferable to the host because additional energy is available from fermentation in the large intestine. 


\section{REFERENCES}

(1) Bernailer A, Lelait M, Rochet V, Grivet J-P, Gibson GR, Durand M. 1996. Acetogenesis from $\mathrm{H}_{2}$ and $\mathrm{CO}_{2}$ by methane- and non-methane-producing human colonic bacterial communities. FEMS Microbiol Ecol 19: 193-202.

(2) Bernalier A, Rochet V, Leclerc M, Doré J, Pochart P. 1996. Diversity of $\mathrm{H}_{2} / \mathrm{CO}_{2}$-utilizing acetogenic bacteria from feces of non-methane-producing humans. Curr Microbiol 33: 94-99.

(3) Chassard C, Bernalier-Donadille A. 2006. $\mathrm{H}_{2}$ and acetate transfers during xylan fermentation between a butyrate-producing xylanolytic species and hydrogenotrophic microorganisms from the human gut. FEMS Microbiol Lett 254: 116-122.

(4) Cummings JH. 1995. Short chain fatty acids. In Human Colonic Bacteria: Role in Nutrition, Physiology and Pathology, Gibson GR, Macfarlane GT (eds), CRC Press, London, p. 101-130.

(5) Deplancke B, Hristova KR, Oakley HA, McCracken VJ, Aminov R, Mackie RI, Gaskins HR. 2000. Molecular ecological analysis of the succession and diversity of sulfate-reducing bacteria in the mouse gastrointestinal tract. Appl Environ Microbiol 66: 2166-2174.

(6) Doré J, Pochart P, Bernalier A, Goderel I, Morvan B, Rambaud JC. 1995. Enumeration of $\mathrm{H}_{2}$-utilizing methanogenic archaea, acetogenic and sulfatereducing bacteria from human feces. FEMS Microbiol Ecol 17: 279-284.

(7) Gibson GR. 1990. A review: physiology and ecology of the sulphate-reducing bacteria. J Appl Microbiol 69: 769-797.

(8) Gibson GR, Cummings JH, Macfarlane GT, Allison C, Segal I, Vorster HH, Walker ARP. 1990. Alternative pathways for hydrogen disposal during fermentation in the human colon. Gut 31: 679-683.

(9) Gibson GR, Macfarlane GT, Cummings JH. 1988. Occurrence of sulphate-reducing bacteria in human faeces and the relationship of dissimilatory sulphate reduction to methanogenesis in the large gut. J Appl Bacterial 65: 103-111.

(10) Gibson GR, Macfarlane GT, Cummings JH. 1993. Sulphate reducing bacteria and hydrogen metabolism in the human large intestine. Gut 34: 437-439.

(11) Godon JJ, Zumstein E, Dabert P, Habouzit F, Moletta R. 1997. Molecular microbial diversity of an anaerobic digester as determined by small-subunit rDNA sequence analysis. Appl Environ Microbiol 63: 2802-
2813.

(12) Hackstein JHP, van Alen TA, Op Den Camp H, Smith A, Mariman E. 1995. Intestinal methanogenesis in primates - a genetic and evolutionary approach. Dtsch tierärztl Wschr 102: 152-154.

(13) Leaphart AB, Lovell CR. 2001 Recovery and analysis of formyltetrahydrofolate synthetase gene sequences from natural populations of acetogenic bacteria. Appl Environ Microbiol 67: 1392-1395.

(14) Ljungdahl LG. 1986. The autotrophic pathway of acetate synthesis in acetogenic bacteria. Ann Rev Microbiol 40: 415-450.

(15) Matsuda K, Tsuji H, Asahara T, Kado Y, Nomoto K. 2007. Sensitive quantitative detection of commensal bacteria by rRNA-targeted reverse transcription-PCR. Appl Environ Microbiol 73: 32-39.

(16) Miller TL, Wolin MJ, de Macario EC, Macario AJ. 1982. Isolation of Methanobrevibacter smithii from human feces. Appl Environ Microbiol 43: 227-232.

(17) Moore JWE, Babidge W, Millard S, Roediger WEW. 1997. Effect of sulphide on short chain acyl-CoA metabolism in rat colonocytes. Gut 41: 77-81.

(18) Ohashi Y, Igarashi T, Kumazawa F, Fujisawa T. 2007. Analysis of acetogenic bacteria in human feces with formyltetrahydrofolate synthetase sequences. Biosci Microflora 26: 37-40.

(19) Robert C, Del'Homme C, Bernalier-Donadille A. 2001. Interspecies $\mathrm{H}_{2}$ transfer in cellulose degradation between fibrolytic bacteria and $\mathrm{H}_{2}$-utilizing microorganisms from the human colon. FEMS Microbiol Lett 205: 209-214.

(20) Roediger WEW, Moore J, Babidge W. 1997. Colonic sulfide in pathogenesis and treatment of ulcerative colitis. Dig Dis Sci 42: 1571-1579.

(21) Sakata T. 1997. Influence of short-chain fatty acids on intestinal growth and functions. In Dietary Fiber in Health and Disease, Kristchevsky D, Bonfield C (eds), Plenum Press, New York, p. 191-199.

(22) Segal I, Walker AR, Lord S, Cummings JH. 1988. Breath methane and large bowel cancer risk in contrasting African populaton. Gut 29: 608-613.

(23) Ufnar JA, Ufnar DF, Wang SY, Ellender RD. 2007. Development of swine-specific fecal pollution marker based on host differences in methanogen mcrA genes. Appl Environ Microbiol 73: 5209-5217.

(24) Wolin MJ, Miller TL. 1983. Interactions of microbial populations in cellulose fermentation. Fed Proc 42: 109-113. 